July 2015

\title{
The Abortion Decision: What About Dad?
}

Erica C. Graham

Cedarville University

Follow this and additional works at: http:// digitalcommons.cedarville.edu/

bioethics_in_faith_and_practice

Part of the Bioethics and Medical Ethics Commons

DigitalCommons@Cedarville provides a publication platform for fully open access journals, which means that all articles are available on the Internet to all users immediately upon publication. However, the opinions and sentiments expressed by the authors of articles published in our journals do not necessarily indicate the endorsement or reflect the views of DigitalCommons@Cedarville, the Centennial Library, or Cedarville University and its employees. The authors are solely responsible for the content of their work. Please address questions to dc@cedarville.edu.

\section{Recommended Citation}

Graham, Erica C. (2015) "The Abortion Decision: What About Dad?," Bioethics in Faith and Practice: Vol. 1 : No. 1 , Article 3. DOI: $10.15385 /$ jbfp.2015.1.1.3

Available at: http://digitalcommons.cedarville.edu/bioethics_in_faith_and_practice/vol1/iss1/3 


\title{
The Abortion Decision: What About Dad?
}

Browse the contents of this issue of Bioethics in Faith and Practice.

\author{
About the Author(s) \\ Erica Graham is a student at Cedarville University.
}

\section{Institution/Affiliation}

Cedarville University

\begin{abstract}
The modern utilitarian abortion debate focuses on how women are affected by abortion but has neglected the utilitarian concerns of men. Abortion is currently justified based on ethical claims that apply to both men and women equally. These ethical claims include empowerment in reproductive decisions, not desiring to become a parent, socioeconomic concerns, moral responsibility over children, pregnancy resulting from coercion, and autonomy. This paper reveals the equivalent ethical claims of men and women to these claims and argues for men having a legal say in deciding whether or not to abort.
\end{abstract}

\section{Keywords}

Abortion, gender equality

\section{Creative Commons License}

\section{(c) (1) (9)}

This work is licensed under a Creative Commons Attribution-Noncommercial-No Derivative Works 4.0 License. 


\section{The Abortion Decision: What About Dad?}

\section{Erica Graham \\ Cedarville University}

Abortion has been debated publically ever since it became possible without seriously risking the woman's life. Recently, this debate has shifted its focus to utilitarian concerns. Both sides argue either for or against abortion based on the benefits for and harms to the mother. ${ }^{1}$ During the consideration of the physical and psychological effects of abortion, an important person has been neglected; the father. Fathers are greatly affected by abortion. In this paper I will argue that if we maintain current utilitarian arguments, then men should have an equal say in the decision to abort because these arguments apply not only to women but also to men. I will then discuss an appropriate response to this conclusion.

One common argument for abortion is that it empowers women and makes them less helpless in reproductive decisions. This is true for women, but what is the current situation for men? Today's system requires a man to pay child support if a child is born but gives him no legal say after conception as to whether or not he wants to be a father. However, women have the ability to choose to become a mother after conception occurs. This is inconsistent with men and women having "equal rights and duties;" a standard modern society desires to uphold. ${ }^{2}$ Men do not currently have the same range of options that women have when an unplanned or unwanted pregnancy occurs. Our society essentially gives men the singular option of pleading with a pregnant woman to have an abortion if he does not desire to be a father. ${ }^{3}$ Men "may feel that the woman holds his fate in her hands and can shape the rest of his life how she sees fit". ${ }^{4}$ If society does not give men an equal say, then they have rendered women all-powerful and men powerless. If women are able to decide after conception not to become mothers, then men should be able to decide not to become fathers after conception.

When considering having an abortion, women don't just want to end pregnancy, but also want to avoid becoming mothers. Some argue that becoming a mother negatively impacts women because it forces them into a role they may or may not desire to play. ${ }^{5}$ Men and women share this motivation for abortion. "When a prospective father wishes that the prospective mother would abort, he does so because he does not want to become a father". ${ }^{6}$ Without a say in abortion decisions, men are essentially forced into fatherhood regardless of if they desire to become a father. Both women and men should be able to act on the desire to avoid parenthood. An equal right to "free our life of a certain kind of complication" should exist. $^{7}$ Men and women equally want to avoid what they see as the inconvenience of pregnancy and subsequent raising of a child. Men agree that any given person should have the autonomy to decide whether or not to have children. ${ }^{8}$ Currently, women are the only parties with this right of choice.

Many women chose abortion because they feel "that they do not have room in their life just then to be a mother". 9 This lack of "room" can result from physical, social, or economic conditions. It is true that women have a greater physical investment in raising their child than men do, (pregnancy and breast feeding) but both men and women have economic obligations to their children. As stated above, men are

Bioethics in Faith and Practice vol. 1, no. 1, pp. 9-12. ISSN 2374-1597

(C) 2015, Erica Graham, licensed under CC BY-NC-ND (http://creativecommons.org/licenses/by-nc-nd/4.0/ ) 
currently required to pay child support. It is easy to imagine to a situation in which a man feels he could not economically support a child. In other words, a man may not feel he has rom in his life to be a father. If women have the option to refuse motherhood based on socioeconomic reasons, then men should also be allowed to do so.

The critical difference between the male and female involvement in child bearing is gestation. People use pregnancy to give the mother ultimate moral responsibility over the fetus. ${ }^{10} \mathrm{~A}$ woman has authority over her own body but abortion is not simply a mother's decision about her health. Abortion intimately and significantly involves the life of another; the child. How then should the healthcare decisions of an unborn child be managed? Men and women have equal rights over a child after birth. Assuming that the fetus is a person possessing basic human rights, these rights should not change because of the child's location. However, the mother does have significant moral authority in procedures affecting her health. Because abortion is becoming so safe, it should be considered primarily a procedure affecting the child's existence and secondarily affecting the mother's health. Abortion, then, is a decision involving the health of two individuals (mother and fetus) which two persons have legal and moral authority in the decision (mother and father).With this understanding of the health effects of abortion, it is easy to see that men and women should have equal decision making power because it primarily affects the child over which they usually have equal rights.

A strong argument against abortion is that it can have negative psychological effects on the woman. Men have shown very similar emotional reactions to abortion, especially when it was performed against their wishes or without their knowledge. Men reported feelings of "anger, guilt, depression, helplessness, and grief" and reacted by denying the event and distancing themselves from it. ${ }^{11}$ Like women, men "continue to think about the abortion years after it is over" but, unlike women, lack socially acceptable outlets to talk about their experience. ${ }^{12}$ Under the current circumstances, men have no valid power to avoid a psychologically harmful event like women do. Women can chose or refuse abortion, men cannot.

A significant pro-choice argument is that many women are coerced into sex or are raped and need a way to end the resulting pregnancy. This argument stands on the fact that women are not avoiding a consequence of their irresponsible decision, but rather are removing themselves from bearing the consequences of their rapists' actions. George Harris argues that men need a morally legitimate interest in procreation in order to have a rightful voice in abortion decisions. ${ }^{13}$ His argument implies that women are the only party who can be coerced or forced into having sex that result in a pregnancy. This is not so. It is not hard to imagine a situation in which a woman coerces a man to have sex with her under the false pretense that she uses oral contraceptives. This man has fatherhood thrust upon him just as a woman who is coerced to have sex has motherhood thrust upon her. Both men and women can be deceived or taken advantage of and forced into parenthood. It is an injustice if society allows one party a way out of parenthood but not the other.

A final argument, made famous by Thomson, is that pregnancy is a violation of a woman's autonomy. ${ }^{14}$ As previously stated, men and women have equal rights over the resulting child and equal concerns as potential parents. By killing the fetus, having an abortion is to invade "the morally legitimate interest in procreation of both the father and the mother and thereby to interfere with the man's as well as the woman's autonomy". ${ }^{15}$ The nature of the violation of autonomy is slightly different for men and women 
(pregnancy vs. prolonged financial obligations), but both are morally legitimate claims. If we accept the autonomy argument for women, then we must give men a say in the decision.

A glaring potential problem with requiring paternal consent for abortion is that it could cause a mother to carry a child against her will. This is a legitimate concern as pregnancy carries a multitude of health and financial concerns, but men face a parallel peril; they could be forced to pay child support for eighteen years. Gestation and eighteen years of child support could be considered equivalent since many women do not have extensive complications during pregnancy. It could even be considered easier to have nine months of health than eighteen years of financial stability. While it is impossible to say that in every circumstance pregnancy and eighteen years of financial stability are equally difficult, the commonness of situations in which they would causes one to stop and consider whether men's concerns are being considered with appropriate weight.

Many current abortion arguments revolve around issues that apply not only to potential mothers, but also to potential fathers. Men can lay legitimate ethical claim to the same reasons that currently justify women's abortion rights. Yet, men have no legal right to voice or act on their opinion. Therefore, paternal consent should be required for an abortion to take place. If this does become a legal requirement numerous complications will arise. For example, when a man and woman disagree on the decision they could end up taking it to court. Court cases can take an extended time to be settled and as the pregnancy progresses abortion becomes a higher risk procedure. Court costs would also be thrust on men and women who potentially do not have enough money to afford to raise a child, much less to pay court costs. Some may say that this complicates the process of abortion too much, making it almost unavailable to women. The legal complications involved in requiring paternal consent have an undeniable potential to victimize women to the decisions of men and the legal system. However, we cannot deny men the same rights we give women when they possess identical moral arguments.

What then should society do? I would argue that the solution is not to give fathers legal say in the abortion decision but to, as a society, rethink how we debate abortion. It is the very utilitarian arguments society uses that create the issue of paternal rights. If society no longer uses or accepts the above utilitarian arguments for and against abortion, the issue would most likely disappear. Society needs to return to the basic ethical concern at the root of the abortion debate: the right to life. Society must answer the question of when life begins, and based on that decide how to approach abortion. The problem is that society has been trying to answer this question for generations, and has yet to find an agreeable answer. In our modern age, who is qualified to offer an opinion that both sides will respect? I believe scientists are. As molecular and cellular biology rapidly advance, these scientists can answer exactly when a new biological life begins; at either conception or birth. I believe that modern society would respect scientists' opinion the most out of any party in the debate. This could offer society the solution to the issues arising from utilitarian arguments by providing a new, non-utilitarian foundation for the debate. The answer to these complications lies not in legal actions but in a different perspective on abortion; focusing more on concrete science and the right to life rather than utilitarian moral concerns of multiple parties.

${ }^{1}$ Dennis M. Sullivan, “A Thirty-Year Perspective on Personhood: How Has the Debate Changed?” Ethics and Medicine 17:3 (2001): 177-86. 
${ }^{2}$ Elizabeth Brake, “Fatherhood and child support: Do men have a right to choose?” Journal of Applied Philosophy, 22 (2005): 55-73.

${ }^{3}$ Ezio Di Nucci, Fathers and Abortion. Journal of Medicine and Philosophy, (39) (2014): 444-58.

${ }^{4}$ A. Mavroforou, E. Koumantakis, and E. Michalodimitrakis. "Do Men Have Rights In Abortion? The Greek View.” Med Law 29 (2010): 77-85.

${ }^{5}$ Di Nucci, “Fathers and Abortion”; Soran Reader, “Abortion, Killing, and Maternal Moral Authority.” Hypatia 23:1 (2008): 132-49.

${ }^{6}$ Di Nucci, 453

${ }^{7}$ Stephen L. Ross,“Abortion and the Death of the Fetus.” Philosophy \& Public Affairs 11:3 (1982): 238-39.

${ }^{8}$ A. Mavroforou, "Do Men Have Rights"

${ }^{9}$ Margaret Olivia Little, “Abortion, intimacy, and the duty to gestate,” Ethical Theory and Moral Practice 2 (1999): 312.

${ }^{10}$ Reader, “Abortion, Killing,...”

${ }^{11}$ Mavroforou, 82.

12 Mavroforou, 83.

${ }^{13}$ George W. Harris, “Fathers and Fetuses,” Ethics 96 (1986): 594-603.

${ }^{14}$ J. J. Thompson, “A Defense of Abortion,” Philosophy \& Public Affairs 1:1 (1971): 47-66.

${ }^{15}$ Harris, 596-97. 


\section{Bibliography}

Brake, Elizabeth. "Fatherhood and child support: Do men have a right to choose?” Journal of Applied Philosophy, 22 (2005): 55-73. doi: http:/dx.doi.org/10.1111/j.1468-5930.2005.00292.x

Di Nucci, Ezio “Fathers and Abortion.” Journal of Medicine and Philosophy 39 (2014): 444-58.

Harris, George W. “Fathers and Fetuses.” Ethics 96 (1986): 594-603.

Ives, Jonathan, Heather Draper, Helen Pattison, and Clare Williams. "Becoming a father/refusing fatherhood: an empirical bioethics approach to paternal responsibilities and rights.” Clinical Ethics 3:2 (2008): 75- 84.

Little, Margaret Olivia “Abortion, intimacy, and the duty to gestate.” Ethical Theory and Moral Practice 2 (1999): 295-312.

Mavroforou, Anna, Evgenios Koumantakis, and Emmanuel Michalodimitrakis. "Do Men Have Rights In Abortion? The Greek View.” Med Law 29 (2010): 77-85.

Reader, Soran. “Abortion, Killing, and Maternal Moral Authority.” Hypatia 23:1 (2008): 132-49.

Ross, Stephen L.“Abortion and the Death of the Fetus.” Philosophy \& Public Affairs 11:3 (1982): 232-45.

Sullivan, Dennis M. “A Thirty-Year Perspective on Personhood: How Has the Debate Changed?” Ethics and Medicine 17:3 (2001): 177-86.

Thomson, J. J. “A Defense of Abortion.” Philosophy \& Public Affairs 1:1 (1971): 47-66. 